\title{
ReCENT ADVANCES IN THE FIGHT AGAINST LEISHMANIASIS WITH NATURAL PRODUCTS
}

\author{
AKENDENGUE B.*, NGOU-MILAMA E.*, LAURENS A.** \& HOCQUEMILLER R.**
}

\section{Summary :}

The active compounds obtained from some medicinal plants used traditionally worldwide for the treatment of leishmaniasis are reviewed. Among these active molecules described in recent literature are quinoline alkaloids such as alkyl-2 quinoline and aryl-2 quinoline from Galipea longiflora, isoquinoline alkaloids such as isoguattouregidine from Guatteria foliosa, indole alkaloids such as conodurine and gabunine from Pescheiera van heurkii, terpenes such as jatrogrossidione from Jatropha grossidentata, acetogenins such as senegalene from Annona senegalensis and lignans such as $1+$ |nyasol from Asparagus africanus. Other natural compounds with antileishmanial activity are coumarins, chalcones, lactones, tetralones and saponins. Some of them are known antiprotozoal natural products. These compounds could be used as templates to discover new and effective drugs against leishmaniasis.

KEY WORDS : antileishmanial, leishmaniasis, natural products, alkaloids, terpenes, quinones, coumarins, chalcones, acetogenins, lactone, lignan.
Résumé : DONNÉES RÉCENTES SUR LES COMPOSÉS ACTIFS DE PLANTES MÉDICINALES UTILISÉES DANS LE TRAITEMENT DE LA LEISHMANIOSE

Les composés actifs obtenus à partir de quelques plantes médicinales utilisées en médecine traditionnelle dans le monde pour le traitement de la leishmaniose sont répertoriés. Parmi ces molécules actives recencées au travers de la littérature depuis 1994, on trouve: les alcaloides quinoléiniques tels les 2-alkyl et les 2-aryl quinoléines isolées de Galipea longiflora, les alcaloïdes isoquinoléiques telle que l'isoguattouregidine isolée de Guatteria foliosa, les alcaloïdes indoliques comme la conodurine et la gabunine isolées de Pescheiera van heurkii, les terpènes telle que la jatrogrossidione isolée de Jatropha grossidentata, les acétogénines avec le senegalène isolé d'Annona senegalensis et les lignanes comme le (+) Inyasol isolé d'Asparagus africanus. Les autres composés naturels à activité leishmanicide appartiennent aux différentes classes chimiques suivantes: coumarines, chalcones, lactones, tetralones et saponines. Certains de ces composés naturels ont des propriétés anti-protozoaires bien connues. Ces structures utilisées comme modèles pourraient conduire à l'obtention de nouveaux médicaments actifs contre la leishmaniose.

MOTS CLÉS : antileishmanien, leishmaniose, produits naturels, alcaloïdes, terpènes, quinones, coumarines, chalcones, acétogénines, lactone, lignane.

immunosuppressive conditions and malnutrition are important risk factors, particularly in the Mediterrean areas (Durand et al.,1997) and in Africa.

The development of synthetic chemical drugs over the last years has not led to any new drugs able to effectively cure leishmaniasis. The chemotherapeutic agents used for the treatment of leishmaniasis such as sodium stibogluconate (Pentostam ${ }^{\circledR}$ ), N-methylglucamine antimonate (Glucantime ${ }^{\circledR}$ ), pentamidine (Pentacarinat ${ }^{\circledR}$ ) and Amphotericin B (Fungizone ${ }^{\circledR}$, Ambisome ${ }^{\circledR}$ ) are not active orally and require long-term parenteral administration. They also have serious side effects such as cardiotoxicity and renal toxicity and are expensive (Croft, 1988; Who, 1996). A rising problem is the changing patterns of sensitivity in antimonials (Olliaro \& Bryceson, 1993; Berman, 1997).

Therefore, new drugs are urgently required. Several natural compounds has been investigated in various laboratories. Many of them have shown significant antileishmanial activity (Phillipson et al., 1991a, b; Iwu et al., 1994). These compounds belong the following groups: alkaloids, terpenes, quinones, lactones, cou- 
marins, acetogenins of annonaceae, chalcones, tetralones, lignans and saponins.

This review is an update from 1994 and its aim is to outline the various classes of compounds, recently isolated from higher plants, which are active against leishmaniasis.

\section{ALKALOIDS}

Alkaloids are the most important natural compounds with antileishmanial activity. They occur in many plant families and interesting activities were found in several groups: quinoline alkaloids, isoquinoline alkaloids and indole alkaloids.

\section{Quinoline alkaloids}

The quinoline alkaloids seem to be very active for the treatment of parasitic diseases. Quinine, a quinoline alkaloid isolated first from Cinchona succirubra, was the first effective antimalarial drug to be discovered. The introduction of new synthetic drugs prepared using the quinine as a template did not lead to its use

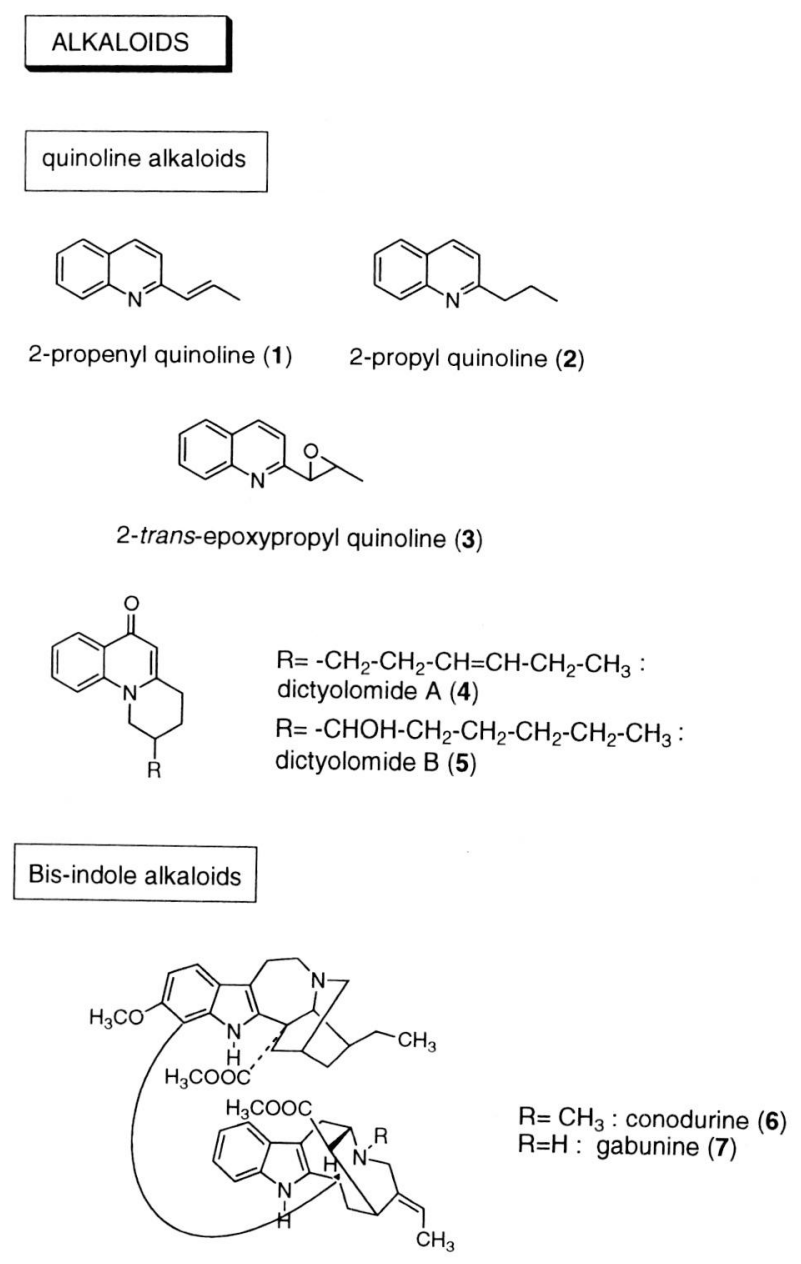

being abandoned by practitioners: quinine is still used to treat severe malaria due to the chloroquine-resistant Plasmodium falciparum.

During an ethnopharmacological investigation in Bolivia, aryl and alkyl-2 quinoline alkaloids active against leishmaniasis were isolated from Galipea longiflora, through a bioactivity-guided fractionation (Fournet et al., 1993).

2-propenyl quinoline (1) and 2-trans epoxypropyl quinoline (3) isolated from the leaves showed antileishmanial activity in vitro against several strains of Leishmania species promastigotes with an $\mathrm{IC}_{90}$ value around $25 \mu \mathrm{g} / \mathrm{ml}$ (147 $\mu \mathrm{M}$ and $135 \mu \mathrm{M}$ respectively). 2-propyl quinoline (2) isolated from the leaves and 4-methoxy 2-phenyl quinoline from bark, root and leaves are less active, with an $\mathrm{IC}_{90}$ value of $50 \mu \mathrm{g} / \mathrm{ml}(292 \mu \mathrm{M}$ and $212 \mu \mathrm{M}$ respectively). The other alkaloids isolated, such as 2-phenyl quinoline, phenyl ethyl quinoline, 2-pentyl quinoline showed antileishmanial activity with an $\mathrm{IC}_{90}$ at $100 \mu \mathrm{g} / \mathrm{ml}$.

In the mouse footpad model infected with Leishmania amazonensis or L. venezuelensis, animals were treated one day after infection with 2-propyl quinoline by the oral route for two weeks at $100 \mathrm{mg} / \mathrm{kg} / \mathrm{day}$. The reference drug, Glucantime ${ }^{\circledR}$, was administrated by subcutaneous injections at $200 \mathrm{mg} / \mathrm{kg} /$ day. Under these conditions 2-propyl quinoline showed the same efficacy as the reference drug in reducing the size of the lesion and the parasite burden. By the same protocol, 2-trans epoxypropyl quinoline appeared slightly more active than Glucantime ${ }^{\circledR}$. Treatment with 2-propenyl quinoline by the oral route or intralesionally for four to six weeks post infection, at the same dose, reduced the parasite load by $95 \%$.

More interestingly, on a model of visceral leishmaniasis, oral administration of propyl quinoline and epoxy propyl quinoline to mice infected with $L$. donovani at $50 \mathrm{mg} / \mathrm{kg} /$ day for five days led to reductions of parasitic load of $87 \%$ and $70 \%$ respectively. A ten-days treatment with 2-propyl quinoline showed a reduction of the parasite burden by $99 \%$.

In the same group, dictyolomide A (4) and dictyolomide B (5), 4-quinolinone alkaloids isolated from the stem bark of Dictyoloma peruviana have in vitro antileishmanial activity against the promastigote forms of L. amazonensis at $50 \mu \mathrm{g} / \mathrm{ml}(177 \mu \mathrm{M})$ and $100 \mu \mathrm{g} / \mathrm{ml}$ respectively, furthermore dictyolomide A shows also an activity at $25 \mu \mathrm{g} / \mathrm{ml}(88 \mu \mathrm{M})$ (Lavaud et al., 1995). Unfortunately no assay was indicated on amastigote forms.

Isoquinoline alkaloids

Isoquinolines which are active against various species of Leishmania have been isolated from plants belon- 
ging to Annonaceae, Berberidaceae, Hernandiaceae and Menispermaceae.

Some compounds like anonaine and liriodenine isolated from the trunk bark of Annona spinescens have shown in vitro activity against promastigote forms of Leishmania species at $10 \mu \mathrm{g} / \mathrm{ml}(37 \mu \mathrm{M})$ and $25 \mu \mathrm{g} / \mathrm{ml}$ (90 $\mu \mathrm{M}$ ) respectively (Queiroz et al., 1996). Isoguattouregidine isolated from the stem bark of Guatteria foliosa is active against $L$. donovani and L. amazonensis at $100 \mu \mathrm{g} / \mathrm{ml}$ (Mahiou et al., 1994).

Indole alkaloids

Indole alkaloids isolated from several plants used in African traditional medicine to treat leishmaniasis have shown antileishmanial activity. Two bis-indole alkaloids, conodurine (6) and N-demethyl-conodurine (gabunine) (7), recently isolated from leaves and stem bark of Pescheiera van beurkii, are active in vitro against the promastigote forms of L. braziliensis as well as on amastigote forms of L. amazonensis. Gabunine, the most potent, remain active against $L$. braziliensis at $10 \mu \mathrm{g} / \mathrm{ml}$ $(15 \mu \mathrm{M})$. On L. amazonensis amastigotes, it exhibited considerable activity with a survival index (SI) of $3 \%$ at $25 \mu \mathrm{g} / \mathrm{ml}(39 \mu \mathrm{M})$. On the same model, conodurine led to a SI of $47 \%$ at $100 \mu \mathrm{g} / \mathrm{ml}$. In vivo, conodurine at $40 \mathrm{mg} / \mathrm{kg} /$ day administered intralesionally was less active than Glucantime ${ }^{\circledR}$ on the development of $L$. amazonensis lesions in $\mathrm{BALB} / \mathrm{c}$ mice whereas gabunine was devoid of activity (Munoz et al., 1994).

\section{TERPENES}

Diterpenes from various species possess powerful antileishmanial activity. Two terpenes: jatrogrossidione (8) isolated from Jatropha grossidentata and jatrophone from Jatropha isabellii, are active against Leishmania promastigotes with an $\mathrm{IC}_{100}$ of $0.75 \mu \mathrm{g} / \mathrm{ml}(2.4 \mu \mathrm{M})$ and $5 \mu \mathrm{g} / \mathrm{ml}(16 \mu \mathrm{M})$ respectively. Under the same conditions, the $\mathrm{IC}_{100}$ of pentamidine against Leishmania strains is $1 \mu \mathrm{g} / \mathrm{ml}(1.6 \mu \mathrm{M})$. The $\mathrm{IC}_{50}$ of jatrogrossidione is below $0.25 \mu \mathrm{g} / \mathrm{ml}(0.8 \mu \mathrm{M})$ against amastigote forms of Leishmania within macrophages. In vivo, jatrophone at $25 \mathrm{mg} / \mathrm{kg} /$ day administered subcutaneously is significantly active against the virulent strain of $L$. amazonensis (PH8), but proved to be too toxic for a clinical use (Schmeda-Hirshmann et al., 1995).

Amarogentin (9), a secoiridoid glycoside isolated from the aerial parts of Swertia chirata is a potent inhibitor of DNA topoisomerase I from Leishmania at $30 \mu \mathrm{M}$ (Ray et al., 1996).

\section{COUMARINS}

5-methyl-coumarin, cycloisobrachycoumarinone epoxide (10) and its 2'-epimer (11) isolated from the roots of Vernonia brachycalyx, have shown the same level of growth inhibition towards L. major promastigotes with
$\mathrm{IC}_{50}$ values of $13.4 \mu \mathrm{g} / \mathrm{ml}(39 \mu \mathrm{M})$ and $12.7 \mu \mathrm{g} / \mathrm{ml}$ $(37 \mu \mathrm{M})$ respectively. In the same test, the $\mathrm{IC}_{50}$ of Pentostam $^{\circledR}$ was $67.3 \mu \mathrm{g} / \mathrm{ml}(199 \mu \mathrm{M})$ but comparaisons of antipromastigote activity with pentavalent antimonials (Pentostam) are pointless as these drugs are poorly active against this stage of the parasite life cycle. These two coumarins do not affect the immune system at the concentrations effective against the parasites (Oketch-Rabah et al., 1997a).

\section{Chalcones}

Licochalcone A (12) isolated from Glycyrrbiza glabra, $G$. uralensis and $G$. inflata roots at $0.5 \mu \mathrm{g} / \mathrm{ml}(1.4 \mu \mathrm{M})$ reduced the infection rate of human peripheral blood monocyte-derived macrophages with L. major amastigotes and exhibited a strong intracellular killing of parasite without to be toxic to host cells. These data show that intracellular Leishmania amastigotes are more susceptible than promastigotes to licochalcone A (Chen M. et al., 1993). On a model of visceral leishmaniasis, the compound administered intraperitoneally at $20 \mathrm{mg} / \mathrm{kg} /$ day and orally at 5 to $150 \mathrm{mg} / \mathrm{kg} /$ day for six days led to reductions of parasite load in the liver and in the spleen of $96 \%$ and $65-85 \%$ respectively. Its intraperitoneal administration at $2.5 \mathrm{mg} / \mathrm{kg} /$ day completely prevented lesion development in BALB/c mice infected with L. major (Chen et al., 1994).

E-1-[2,4-dihydroxy-3-(3-methyl-2-butenyl)phenyl(-3-(4hydroxy-3-(3-methyl-2-butenyl) phenyl]-2-propen-1one, a chalcone (13) isolated from roots bark of Glycyrrbiza inflata showed potent in vitro antileishmanial activity against $L$. donovani promastigotes with an $\mathrm{IC}_{90}$ of $10 \mu \mathrm{g} / \mathrm{ml}(25 \mu \mathrm{M})$ (Brogger Christensen et al., 1994).

\section{ACETOGENINS FROM ANNONACEAE}

Acetogenins isolated from Annona senegalensis seeds possess antileishmanial activity. The mono-tetrahydrofuranic acetogenin, senegalene (14), has been shown to be active against $L$. major and $L$. donovani at the concentrations of $50 \mu \mathrm{g} / \mathrm{ml}(80 \mu \mathrm{M})$ and $25 \mu \mathrm{g} / \mathrm{ml}$ $(40 \mu \mathrm{M})$ respectively. In the bis-tetrahydrofuranic series, squamocine (15) and molvizarine are also effective at the same level. Pentamidine, the reference drug, was approximately twice as efficient as these acetogenins (Sahpaz et al., 1994). Nevertheless this class of compounds is known to be cytotoxic. Toxicity on macrophages and assay on amastigote form are necessary to show their interest on leishmania.

\section{MiscellaneOUS}

(+)Nyasol (16), a lignan isolated from the roots of Asparagus africanus showed, in vitro, inhibition of the growth of $L$. major promastigotes with an $\mathrm{IC}_{50}$ value of $12 \mu \mathrm{M}$, but this concentration also slightly affected 
the proliferation of human lymphocytes (Oketch-Rabah et al., 1997b).

Muzunzagenin (17), a sapogenin isolated from Asparagus africanus has been shown to possess moderate in vitro leishmanicidal activity, the $\mathrm{IC}_{50}$ against $L$. major promastigotes being $70 \mu \mathrm{M}$ (Oketch-Rabah et al., 1997b).

Argentilactone (18), an $\alpha-\beta$ unsaturated $\delta$-lactone isolated from the roots of Annona baematantha, exhibited in vitro activity against various strains of Leishmania at $10 \mu \mathrm{g} / \mathrm{ml}(51 \mu \mathrm{M})$. In vivo, administered by the subcutaneous route at $25 \mathrm{mg} / \mathrm{kg} /$ day for 14 days, the compound produced the same effect as N-methylglucamine antimonate, the reference drug, decreasing the size of lesions in mice infected with $L$. amazonensis (Waechter et al., 1997).

4-hydroxy-1-tetralone (19) isolated from the stem bark of Ampelocera edentula, has shown in vitro activity

\section{CHALCONES}<smiles>C=CC(C)(C)c1cc(/C=C/C(=O)c2ccc(O)cc2)c(OC)cc1O</smiles>

licochalcone A (12)<smiles>CC(C)=CCc1cc(/C=C/C(=O)c2ccc(O)c(CC=C(C)C)c2O)ccc1O</smiles>

chalcone (13) against promastigote forms of various strains of Leishmania with an $\mathrm{IC}_{90}$ of $10 \mu \mathrm{g} / \mathrm{ml}(61 \mu \mathrm{M})$. In vivo at 25 $\mathrm{mg} / \mathrm{kg} /$ day in mice infected with L. amazonensis (PH8) or L. venezuelensis this compound was slightly less active than Glucantime ${ }^{\circledR}$ (Fournet et al., 1994).

\section{TERPENES}<smiles></smiles>

jatrogrossidione (8)

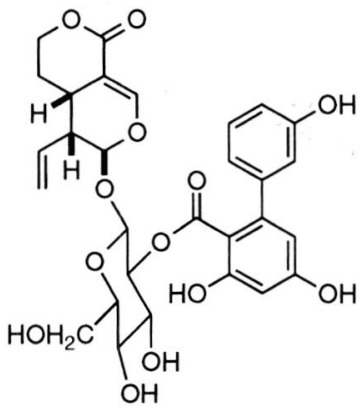

amarogentin (9)

\section{COUMARINS}<smiles>[R8][C@@]1([2H])Oc2c(c(=O)oc3cccc(C)c23)[C@]1(C)C(=O)C1OC1(C)C</smiles>

$\mathrm{R}_{1}=\mathrm{H}, \mathrm{R}_{2}=\mathrm{CH}_{3}$ :

cycloisobrāchycoumarinone epoxide (10)

$\mathrm{R}_{1}=\mathrm{CH}_{3}, \mathrm{R}_{2}=\mathrm{H}$ :

2'-epicycloisobrachycoumarinone epoxide (11)

\section{ACETOGENINS}<smiles></smiles>

senegalene (14)<smiles>CCCCCC[C@H](O)CCC[C@@H](O)[C@H]1CC[C@H]([C@H]2CC[C@H]([C@H](O)CCCCCCCCCCCCC3=C[C@H](C)OC3=O)O2)O1</smiles> 
<smiles>C=CC(/C=C\c1ccc(O)cc1)c1ccc(O)cc1</smiles>

(+)nyasol (16)

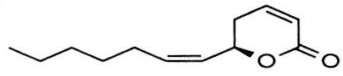

argentilactone (18)

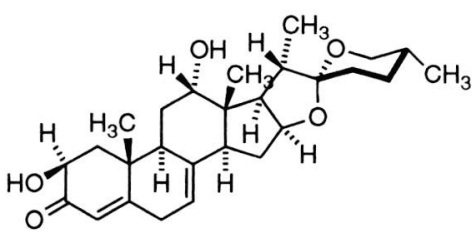

muzanzagenin (17)<smiles>O=C1CCC(O)c2ccccc21</smiles>

tetralone (19)
Diospyrin, a bisnaphthoquinone isolated from the stem-bark of Diospyros montana, active against $L$. donovani promastigote forms at $1 \mu \mathrm{g} / \mathrm{ml}$ (Phillipson et al., 1991b) was tested in vitro against intracellular amastigotes in macrophages (Yardley V. et al., 1996). This compound was inactive at $10 \mu \mathrm{M}$ but synthetic derivatives obtained by minor changes in the functionnal groups of diospyrin had improved the antileishmanial activity.

2-benzoxazolinone isolated from the leaves of Acanthus illicifolius possesses a leishmanicidal activity in vitro against $L$. donovani promastigotes with an $\mathrm{IC}_{50}$ of $40 \mu \mathrm{g} / \mathrm{ml}(296 \mu \mathrm{M})$ (Kapil et al., 1994).

\section{CONCLUSION}

$\mathrm{V}$ Tarious natural chemical compounds possess antileishmanial activity. Several of them are active against promastigote forms, nevertheless to confirm their interest, activity assays on amastigote forms as well as the evaluation of their toxicity on macrophages are necessary. Furthermore, in vivo assays, by different routes allow to confirm the biological interest of these compounds on leishmaniasis. All these compounds could be interesting leads for further development of antileishmanials drugs. Most of them have been isolated from medicinal plants used in traditional medicines using bioassay-guided fractionation. In this review, a few, such as alkyl quinoline and licochalcone, are quite simple to synthesize, thus allowing the development of low-cost drugs for chemotherapy of leishmaniasis in developing countries.

\section{REFERENCES}

Balana-Fouce R., Reguera R.M., Cubria J.C. \& Ordonez D. The pharmacology of leishmaniasis. General Pharmacology 1998, 30, 435-443.

Berman J.D. Human leishmaniasis: clinical, diagnostic, and chemotherapeutic developments in the last 10 years. $\mathrm{Cli}$ nical Infectious Diseases, 1997, 24, 684-703.

Brogger Christensen S., Chen Ming, Andersen L., Hjorne U., Olsen C.E., Cornett C., Theander T.G. \& Kharazmi A. An antileishmanial chalcone from Chinese licorice roots. Planta Medica, 1994, 60, 121-123.

Chen M., Brogger Christensen S., Blom J., Lemmich E., Nadelmann L., Fich K., Theander T.G. \& Kharazmi A. Licochalcone A, a novel antiparasitic agent with potent activity against human pathogenic protozoan species of Leishmania. Antimicrobial Agents and Chemotherapy, 1993, 37, 2550-2556.

Chen M., Brogger Christensen S., Theander T.G. \& KHARAZMI A. Antileishmanial activity of licochalcone A in mice infected with Leishmania major and in hamsters infected with Leishmania donovani. Antimicrobial Agents and Chemotherapy, 1994, 38, 1339-1344.

Croft S.L. Recent developments in the chemotherapy of leishmaniasis. Trends in Pharmacological Sciences, 1988, 9, 376-381.

Durand R., Paul M., Rivollet D., Fessi H., Houin R., Astier A \& Deniau M. Activity of pentamidine-loaded poly (D, Llactide) nanoparticles against Leishmania infantum in a murine model. Parasite, 1997, 4, 331-336.

Fournet A., Hocquemiller R., Roblot F., CaVe A., Richomme P. \& Bruneton J. Les chimanines, nouvelles quinoléines substituées en 2, isolées d'une plante bolivienne antiparasitaire: Galipea longiflora. Journal of Natural Products, 1993, 56, 1547-1552. 
Fournet A., Angelo Barrios A., Munoz V., Hocquemiller R. Roblot F. \& CAve A. Antileishmanial activity of a tetralone isolated from Ampelocera edentula, a bolivian plant used as a treatment for cutaneous leishmaniasis. Planta Medica, 1994, 60, 8-12.

Iwu M.M., Jackson J.E. \& Schuster B.G. Medicinal plants in the fight against leishmaniasis. Parasitology Today, 1994, 10, 65-68.

Kapil A., Sharma S. \& Wahidulla S. Leishmanicidal activity of 2-benzoxalinone from Acanthus illicifolius in vitro. Planta Medica, 1994, 60, 187-188.

lavaud C., Massiot G., Vasquez C., Moretti C., Sauvain M. \& Balderrama L. 4-quinolinone alkaloids from Dictyoloma peruviana. Pbytochemistry, 1995, 40, 317-320.

Mahiou V., Roblot F., Hocquemiller R., Cave A., Rojas De Arias A., Inchausti A., Yaluff G., Fournet A. \& Angelo A. New aporphine alkaloids from Guatteria foliosa. Journal of Natural Products, 1994, 57, 890-895.

Munoz V., Moretti C., Sauvain M., Caron C., Porzel A., MasSIOT G., Richard B. \& Le MEN-Olivier L. Isolation of bisindole alkaloids with antileishmanial and antibacterial activities from Peschiera van beurkii (Syn. Tabernaemontana van beurkii). Planta Medica, 1994, 60, 455-459.

Oketch-Rabah H.A., Lemmich E., Dossaji S.F., Theander T.G., Olsen C.E., Cornett C., Kharazmi A. \& Brogger ChrisTENSEN S. Two new antiprotozoal 5-methylcoumarins from Vernonia brachycalyx. Journal of Natural Products, 1997 , 60, 548-461.

OKeTCh-Rabah H.A. \& Dossaji S.F. Antiprotozoal compounds from Asparagus africanus. Journal of Natural Products, 1997, 60, 1017-1022.

Olliaro P.L. \& Bryceson A.D.M. Practical progress and new drugs for changing patterns of leishmaniasis. Parasitology Today, 1993, 9, 323-328

Phillipson J.D. \& Wright C.W. Medicinal plants in tropical medicine: medicinal plants against protozoal diseases. Transactions of the Royal Society of Tropical Medicine and Hygiene, 1991a, 85, 18-21.

Phillipson J.D. \& Wright C.W. Antiprotozoal agents from plant sources. Planta Medica, 1991b, 57, 53-59.

Queiroz E.F., Roblot F. \& Cave A. Pessoine and spinosine, two catecholic berberines from Annona spinescens. Journal of Natural Products, 1996, 59, 438-440.

Ray S., Majumder H. K., Chakravarty A. K. \& MukhopaDHYAY S. Amarogentin, a naturally occurring secoiriodoid glycoside and a newly recognized inhibitor of topoisomerase I from Leishmania donovani. Journal of Natural Products, 1996, 59, 27-29.

Sahpaz S., Bories C., Loiseau P.M., Cortes D., Hocquemiller R., Laurens A. \& Cave A. Cytotoxic and antiparasitic activity from Annona senegalensis seeds. Planta Medica, 1994, 60, 538-540.

Schmeda-Hirschman G., Razmilic I., Sauvain M., Moretti C., Munoz V., Ruiz E., Balanza E. \& Fournet A. Antiprotozoal activity of jatrogrossidione from Jatropha grossidentata and jatrophone from Jatropha Isabelli. Phytotherapy Research, 1996, 10, 375-378.
Waechter A.I., Ferreira M.E., Fournet A., Rojas De Arias A., Nakayama H., Torres S., Hocquemiller R. \& Cave A. Experimental treatment of cuteanous leishmaniasis with argentilactone isolated from Annona baematantha. Planta Medica, 1997, 63, 433-435.

WhO (Arias J., Desjeux P. \& Miles M.A.). Manuel de lutte contre la leishmaniose viscérale WHO/LEISH/96.40. Organisation Mondiale de la Santé, Division de la lutte contre les maladies tropicales, Geneva, Swiss, 1996.

Yardley V., SnOwdon D., Croft S. \& Hazra B. In vitro activity of diospyrin and derivatives against Leishmania donovani, Trypanosoma cruzi and Trypanosoma brucei brucei. Phytotherapy Research, 1996, 10, 559-562.

Reçu le 3 septembre 1998 Accepté le 12 novembre 1998 